\title{
The Cryobiotechnology of Oaks: An Integration of Approaches for the Long-Term Ex Situ Conservation of Quercus Species
}

\author{
Daniel Ballesteros *(D) and Hugh W. Pritchard $(\mathbb{D}$ \\ Comparative Seed Biology, Department of Comparative Plant and Fungal Biology, Royal Botanic Gardens Kew, \\ Wakehurst Place, West Sussex RH17 6TN, UK; h.pritchard@kew.org \\ * Correspondence: d.ballesteros@kew.org
}

Received: 6 November 2020; Accepted: 26 November 2020; Published: 29 November 2020

\begin{abstract}
Conventional dry seed storage is unlikely for about one third of all tree species (and nearly half of evergreen rain forest trees) as they probably produce desiccation sensitive (recalcitrant) seeds. Consequently, international ex situ conservation targets for threatened trees will be difficult to achieve without innovation, especially in cryobiotechnology. We assessed progress in the development of various cryobiotechnology approaches for the preservation of oaks (Quercus), which are keystone species of functioning landscapes, important to the bioeconomy and under increasing threats from the spread of pests and diseases under a changing climate. Various tissues of oaks can be used for banking, from pollen grains to embryo axes. Pollen from five oak species have been shown to be highly desiccation tolerant, making dry pollen storage at low temperatures (including in liquid nitrogen) a valuable technology to support conservation and breeding programs. Somatic embryo (SE) technology and/or shoot tip in vitro technology is available for 39 species, and SE cryopreservation is routinely performed on three commercial species and shoot tips cryopreservation successful in two more species. Seed embryonic axes are the preferred explants for oak ex situ conservation, with tissue survival and regeneration of plants after cryopreservation recorded for 14 and seven species respectively; although differential responses between the shoot and root meristems in the axes are known. Dormant bud preservation seems promising, but is under-researched. Overall, these results indicate the possibility of establishing an integrated platform for the ex situ conservation of oak species based on cryobiotechnology. Challenges of explant choice, optimization of methodologies and large-scale application do remain. However, multiple approaches for the cryopreservation of oak genetic resources are available and implementation programmes should not be delayed, particularly in the centres of species diversity.
\end{abstract}

Keywords: cryopreservation; DOE; dormant buds; embryonic axes; in vitro culture; pollen; shoot tips; tree genetic resources; recalcitrant seeds

\section{Introduction}

Trees are anchors of the forest, providing crucial resources for shelter, food and medicines and supporting livelihoods. They are directly or indirectly essential for the survival of many wild ecosystems and agrobiodiverse landscapes, and have immense cultural importance. However, it is estimated that ca. 10,000 of the world's tree species are threatened with extinction [1] and the target of renewed efforts for their ex situ conservation. For example, Target 8 of the Global Strategy for Plant Conservation (GSPC), of the Convention on Biological Diversity (CBD), calls for "At least 75\% of threatened plant species in ex situ collections, preferably within the country of origin, and at least $20 \%$ available for recovery and restoration programmes" by 2020 [2]. However, only $26 \%$ of threatened trees are reported 
as conserved in ex situ collections (by means of cultivated plants and seed stored in seed banks) and the majority of trees are represented in a single or small number of collections [1]. Moreover, the CBD's Aichi Biodiversity Target 12, on improving the conservation status of known threatened species, has not been achieved, according to the Global Biodiversity Outlook 5 [3]. Such findings confirm the urgent need to redirect resources from identifying threatened species to actioning conservation intervention.

The most applied strategy for the ex situ conservation of plant species is the storage of dry seeds in biobanks operating at $-20^{\circ} \mathrm{C}$ [4-6]. However, such conventional seed banking is not suitable for a large proportion of tree species. For example, it is estimated that $33 \%$ of tree species might produce desiccation sensitive (recalcitrant) seeds that die on drying; this value could be ca. $47 \%$ for evergreen rain forest trees $[7,8]$. This seed physiology trait then explains the low proportion of threatened trees conserved in ex situ collections [1,9]. The wider implication is that many tropical, subtropical and temperate trees that are canopy-forming or landscape dominants, need innovative solutions for their conservation; preferable a range of options that enable the integration of ex situ with in situ approaches.

For species with recalcitrant seeds, cryopreservation has been shown to be the most promising technology for their long-term conservation [5,10,11]. Unlike conventional seed banking, numerous tissues of trees can be used for banking at ultra-low temperature, including winter dormant buds, shoot tips, embryogenic calli, somatic embryos, embryonic axes, plumules and pollen [11-13]. With respect to the preservation of the genetic resource, the different tissues provide various options for the haploid and diploid genome, and the paternal and maternal lines. This has made the large-scale long-term ex situ conservation of tree genetic resources a reality for a wide range species with economic and food value, such as fruit trees, and forestry and plantation species [12,14-16]. However, standard long-term conservation strategies for wild, particularly threatened, species are far less developed $[1,11,17]$. Moreover, no single method of preservation is appropriate for all propagules or tissues. Rather, multiple approaches are needed to bring a wider range of tree species into long-term storage [11,18,19].

We have focused this review on Quercus sp. for two reasons: the importance of oaks in most of the north hemisphere forests [20], and the lack of large-scale long-term conservation initiatives for the conservation of the c. 600 wild oak species, particularly those that are threatened [17]. The conclusions we make about progress on the cryobiotechnology of oaks should help with the development of appropriate strategies for the long-term ex situ conservation of other taxa, particularly those with low or nil representation in ex situ conservation programmes, whether threatened and/or recalcitrant seeded $[1,9]$.

\section{Oaks, the Case Study}

Oaks (Quercus sp.) are dominant trees in most European, North African, American and Asian forests, from cool temperate to tropical environments, on which thousands of other species depend on. They are an important source of timber and coppice wood, but also are used to produce fuelwood, charcoal, medicinal products, dyes, cork and bark used in tanning [20]. Acorns provide animal fodder in important food industries such as the Spanish Iberico ham [21], and many species of oak are grown ornamentally around the world [20]. There are at least 600 species of Quercus globally [22], however, $45 \%$ of the species evaluated by IUCN are considered threatened [20], being affected by habitat destruction or diseases and pests, such as, sudden oak death, acute oak decline or chronic oak dieback [14,17]. Consequently, the conservation of oaks is increasingly important in many countries [1,14,17,20]. As most species of Quercus have desiccation sensitive (i.e., recalcitrant) seeds [23], their long-term conservation ex situ, beyond limited individuals in living collections in botanic gardens, depends on the development and application of cryobiotechnology [19]. In the first instance, progress is needed to support the few initiatives there are on the conservation of elite Quercus genotypes, i.e., a few species with economical interest [14,17]. 


\section{Whole Seed (Acorn) Storage}

Desiccation sensitivity in the acorns (fruits) and seeds of Quercus sp. [23] precludes storage in conventional seed banks [6] and contributes to their death after non-dry storage in liquid nitrogen (LN) [24]. However, such seeds can be stored briefly in hydrated storage at, typically, close to $0{ }^{\circ} \mathrm{C}$ (FAO, 2014); for example, storage at near-full hydration (30-50\% moisture contents) at low temperatures $\left(-3\right.$ to $\left.+4{ }^{\circ} \mathrm{C}\right)$ [25-28]. Under such conditions acorn viability can be maintained for 6-24 months, and in some temperate species up to a few years. This is of benefit to the provision of planting stock for reintroduction and restoration programmes. However, extending storage for this period remains a challenge, particularly for warm-temperate/tropical oaks; these may be sensitive to chilling injury, thus precluding hydrated storage at close to $0{ }^{\circ} \mathrm{C}$. Understanding the interspecies variability in the response to hydrated storage at low temperatures may be important to find stress tolerance biomarkers (e.g., ecological, structural, genetic and molecular) that may hold some lessons for the optimization of the design of cryopreservation strategies.

\section{Tissue Culture and Preservation by In Vitro Collections}

Tissue culture (in vitro culture or micropropagation) is an important applied tool within cryobiotechnology for the conservation of many plant species [4,29-31]. Within plant genetic resources conservation, the four main applications are: (1) maintaining germplasm collections in vitro for medium-term storage $[4,14,31,32]$; (2) increasing the number of individuals in a population for use in reintroductions or reforestation, both outside and inside native habitat $[4,31]$; (3) supplying shoot tips or somatic embryos for cryopreservation [14,29-31] and (4) recovering growth in isolated embryo axes following the application of a cryopreservation protocol [33-36].

Overall, tissue culture research on mainly shoots or somatic embryos has extended to at least 39 Quercus sp. (Table 1). Of these, over a third (14 species) are listed as being near threatened or under greater risk of extinction based on IUCN criteria.

Juvenile and mature tissue material has been used, usually from shoots or buds but also from leaves $[14,17]$. Mature material tends to be more difficult to establish and grow in culture due to the high contamination rates and the low regeneration potential of their cells $[14,37]$. This problem requires deep morphogenetical studies to understand why some cells/parts of the tree are more competent than others and what leads the differences in response to diverse oak species [14]. In addition, it requires the appropriate balance of minerals (e.g., $\mathrm{N}$ and $\mathrm{S}$ ) and phytohormones, and extra preparation to produce clean cultures with high shoot regeneration response [37]. However, these challenges need to be addressed when dealing with threatened species [37].

Tissue culture can be used to create and maintain in vitro germplasm collections of Quercus sp. for intermediate-term storage [14,32]. For example, somatic embryos are multiplied by secondary embryogenesis and cultured at about $20-25^{\circ} \mathrm{C}$ in media with varying doses of plant growth regulators depending on the species [14]. As soon as the embryogenic capacity through secondary embryogenesis is maintained, cultures can be subcultured for several (e.g., over 4) years [14]. In addition, Q. suber shoot tips have been maintained in culture at $4{ }^{\circ} \mathrm{C}$ in the dark for at least 6 months with WP medium enriched with $0.1 \mathrm{mg} / \mathrm{L} \mathrm{BA}$ [32]. However, the genetic representation in vitro can be as limited as living collections, i.e., based on a few individuals. For longer-term preservation and better genetic representation it is preferable to use propagules, or parts thereof, and cryopreservation $[4,5,31,44]$. Such an approach is a cost-effective option when considered over the long term, i.e., several decades $[5,10,11,39]$. 
Table 1. Example of Quercus species for which tissue culture have been investigated and developed.

\begin{tabular}{|c|c|c|c|c|}
\hline Species $^{1}$ & Range of Distribution ${ }^{2}$ & Threatened Species $^{3}$ & Tissue Cultured & References \\
\hline Q. acutissima Carruth. & $\begin{array}{l}\text { Native to China (including Tibet), Korea, Japan, } \\
\text { Indochina (Vietnam, Thailand, Myanmar, } \\
\text { Cambodia) and the Himalayas (Nepal, Bhutan, } \\
\text { Northeastern India) }\end{array}$ & NO & Somatic embryos & {$[14,38]$} \\
\hline $\begin{array}{l}\text { Q. acerifolia (E.J.Palmer) Stoynoff } \\
\text { and W.J.Hess ex R.J.Jensen }\end{array}$ & United States (Arkansas) & YES & Somatic embryos; Shoot cultures & [17] \\
\hline Q. alba L. & $\begin{array}{l}\text { Eastern half of the United States, extending } \\
\text { north into southern Ontario and Quebec in } \\
\text { Canada }\end{array}$ & $\mathrm{NO}$ & Shoot cultures & {$[14,38]$} \\
\hline Q. arbutifolia Hickel and A. Camus & China, Vietnam & YES & Shoot cultures & [39] \\
\hline Q. arkansana Sarg. & $\begin{array}{l}\text { United States (Alabama, Arkansas, Florida, } \\
\text { Georgia, Louisiana, Texas) }\end{array}$ & YES & Somatic embryos; Shoot cultures & {$[17,37]$} \\
\hline Q. bicolor Willd. & $\begin{array}{l}\text { North-central and eastern parts of the United } \\
\text { States, extending into parts of south Quebec } \\
\text { and Southeastern Ontario in Canada }\end{array}$ & NO & Shoot cultures & {$[14,38]$} \\
\hline Q. boyntonii Beadle & $\begin{array}{l}\text { United States (Alabama, Texas - Regionally } \\
\text { Extinct) }\end{array}$ & YES & Somatic embryos; Shoot cultures & {$[17,37]$} \\
\hline Q. canbyi Trel. & United States (Texas) & YES & Shoot cultures & [37] \\
\hline Q. canariensis Willd. & $\begin{array}{l}\text { Native to southern Portugal, Spain, Tunisia, } \\
\text { Algeria and Morocco }\end{array}$ & YES & Somatic embryos & {$[38]$} \\
\hline Q. castanea Née & $\begin{array}{l}\text { Native to El Salvador, Guatemala, Honduras } \\
\text { and Mexico }\end{array}$ & NO & Shoot cultures & [40] \\
\hline Q. cerris L. & South-eastern Europe and Asia Minor & $\mathrm{NO}$ & Somatic embryos; Shoot cultures & {$[14,38]$} \\
\hline Q. chrysolepis Liebm. & $\begin{array}{l}\text { Mexico (Baja California); United States } \\
\text { (Arizona, California, Nevada, New Mexico, } \\
\text { Oregon) }\end{array}$ & $\mathrm{NO}$ & Shoot cultures & [37] \\
\hline Q. dumosa Nutt. & $\begin{array}{l}\text { Mexico (Baja California); United States } \\
\text { (California) }\end{array}$ & YES & Shoot cultures & [37] \\
\hline Q. eduardii Trel. & Mexico & NO & Shoot cultures & [40] \\
\hline Q. engelmannii Greene & $\begin{array}{l}\text { Mexico (Baja California); United States } \\
\text { (California) }\end{array}$ & YES & Shoot cultures & [37] \\
\hline $\begin{array}{l}\text { Q. euboica (syn. of Q. trojana subsp. } \\
\text { euboica (Papaioannou)) }\end{array}$ & $\begin{array}{l}\text { Italy and the Balkan peninsula from Croatia, } \\
\text { south to northern Greece. The species is found } \\
\text { in both European and Asian Turkey }\end{array}$ & NO & Shoot cultures & {$[37,39]$} \\
\hline Q. gambelii Liebm. & $\begin{array}{l}\text { Mexico (Chihuahua, Coahuila, Sonora); United } \\
\text { States (Arizona, Colorado, Nevada, New } \\
\text { Mexico, Texas, Utah, Wyoming) }\end{array}$ & NO & Shoot cultures & {$[37,39]$} \\
\hline
\end{tabular}


Table 1. Cont.

\begin{tabular}{|c|c|c|c|c|}
\hline Species $^{1}$ & Range of Distribution $^{2}$ & Threatened Species $^{3}$ & Tissue Cultured & References \\
\hline Q. georgiana M.A. Curtis & $\begin{array}{l}\text { United States (Alabama, Georgia, North } \\
\text { Carolina - Possibly Extinct, South } \\
\text { Carolina-Possibly Extinct) }\end{array}$ & YES & Somatic embryos; Shoot cultures & [17] \\
\hline Q. glauca Thunb & $\begin{array}{l}\text { Native to Assam, China, East and West } \\
\text { Himalaya, Hainan, Japan, Korea, Laos, } \\
\text { Myanmar, Nansei-shoto, Nepal, Taiwan, Tibet } \\
\text { and Vietnam }\end{array}$ & $\mathrm{NO}$ & Shoot cultures & {$[41]$} \\
\hline $\begin{array}{l}\text { Q. graciliformis C.H. Mull. (syn. of } \\
\text { Q. canbyi Trel.) }\end{array}$ & United States (Texas) & YES & Shoot cultures & [37] \\
\hline Q. hinckleyi C.H. Mull. & $\begin{array}{l}\text { Mexico (North Chihuahua); United States } \\
\text { (Texas) }\end{array}$ & YES & Shoot cultures & [39] \\
\hline Q. ilex $\mathrm{L}$. & $\begin{array}{l}\text { Widespread across the Mediterranean and } \\
\text { Balkan regions of Europe, in North Africa and } \\
\text { in Turkey }\end{array}$ & $\mathrm{NO}$ & Somatic embryos & {$[14,38]$} \\
\hline $\begin{array}{l}\text { Q. leucotrichophora A.Camus ex } \\
\text { Bahadur [syn of Q. oblongata D.Don] }\end{array}$ & $\begin{array}{l}\text { Native to Assam, Bangladesh, India, Myanmar, } \\
\text { Nepal, Pakistan, Thailand, Vietnam, West } \\
\text { Himalaya }\end{array}$ & $\mathrm{NO}$ & Shoot cultures & {$[41]$} \\
\hline Q. libani G. Olivier & $\begin{array}{l}\text { Eastern Mediterranean and western Asia } \\
\text { (including Lebanon, western Syria, } \\
\text { northeastern Israel, eastern Turkey, and } \\
\text { northern Iraq and Iran). }\end{array}$ & $\mathrm{NO}$ & Somatic embryos & [38] \\
\hline Q. lusitanica Lam. & Iberian Peninsula (north-west), Morocco & YES & Shoot cultures & [39] \\
\hline Quercus palmeri (Engelm.) Engelm. & $\begin{array}{l}\text { United States (S. California, Arizona) and } \\
\text { Mexico (N. Baja Califonia). }\end{array}$ & YES & Shoot cultures & [37] \\
\hline Q. petraea (Matt.) Liebl. & $\begin{array}{l}\text { Widespread species found in Europe, Russia, } \\
\text { the Caucasus and west Asia }\end{array}$ & $\mathrm{NO}$ & Shoot cultures & {$[14,38]$} \\
\hline $\begin{array}{l}\text { Q. pubescens Brot. (syn. of } Q \text {. } \\
\text { pyrenaica Willd.) }\end{array}$ & $\begin{array}{l}\text { From northern Spain (Pyrenees) east to the } \\
\text { Crimea and the Caucasus. It is also found in } \\
\text { France and parts of central Europe. }\end{array}$ & $\mathrm{NO}$ & Somatic embryos & [38] \\
\hline Q. resinosa Liebm. & Mexico & $\mathrm{NO}$ & Shoot cultures & [40] \\
\hline Q. robur $\mathrm{L}$. & $\begin{array}{l}\text { Very widespread species, found in most } \\
\text { countries in Europe and Russia, The Caucasus, } \\
\text { Iran, Kazakhstan and Turkey }\end{array}$ & NO & $\begin{array}{l}\text { Somatic embryos; } \\
\text { Shoot cultures }\end{array}$ & {$[14,38]$} \\
\hline Q. rubra L. & $\begin{array}{l}\text { Occurs widely throughout eastern North } \\
\text { America, across the eastern US and } \\
\text { southeastern Canada }\end{array}$ & $\mathrm{NO}$ & $\begin{array}{l}\text { Somatic embryos; } \\
\text { Shoot cultures }\end{array}$ & {$[14,38]$} \\
\hline
\end{tabular}


Table 1. Cont.

\begin{tabular}{|c|c|c|c|c|}
\hline Species $^{1}$ & Range of Distribution $^{2}$ & Threatened Species $^{3}$ & Tissue Cultured & References \\
\hline Q. rugosa Née & $\begin{array}{l}\text { United States (Arizona, New Mexico, Texas), } \\
\text { Mexico, Guatemala, Honduras }\end{array}$ & NO & Shoot cultures & [40] \\
\hline Q. semecarpifolia Sm. & $\begin{array}{l}\text { Native to the Himalayas and nearby } \\
\text { mountains in Tibet, Afghanistan, India, Nepal, } \\
\text { and Pakistan }\end{array}$ & YES & Shoot cultures & [37] \\
\hline Q. serrata Murray & $\begin{array}{l}\text { China, Taiwan, Japan, and Korea } \\
\text { Found in Europe and Africa, within }\end{array}$ & NO & Somatic embryos & {$[38,41]$} \\
\hline Q. suber L. & $\begin{array}{l}\text { Mediterranean regions. Within Europe the } \\
\text { species is found from Portugal to Sicily and in } \\
\text { Africa it is found in Morocco, Algeria and } \\
\text { Tunisia }\end{array}$ & NO & $\begin{array}{l}\text { Somatic embryos; } \\
\text { Shoot cultures }\end{array}$ & {$[14,38,39]$} \\
\hline Q. texana Buckley & $\begin{array}{l}\text { United States (Alabama, Arkansas, Illinois, } \\
\text { Kentucky, Louisiana, Mississippi, Missouri, } \\
\text { Oklahoma, Tennessee, Texas) }\end{array}$ & NO & Shoot cultures & [37] \\
\hline Q. tomentella Engelm. & $\begin{array}{l}\text { Mexico (Guadalupe I.); United States } \\
\text { (California) }\end{array}$ & YES & Shoot cultures & {$[37]$} \\
\hline Q. vacciniifolia Hittell & United States (California, Nevada, Oregon) & $\mathrm{NO}$ & Shoot cultures & [37] \\
\hline Q. virginiana Mill. & $\begin{array}{l}\text { United States (Southeaster's Coastal Plain, } \\
\text { from Virginia to Florida and Texas) }\end{array}$ & NO & Shoot cultures & [39] \\
\hline
\end{tabular}

${ }^{1}$ Names authorities follow [42]. ${ }^{2}$ [43]. ${ }^{3}$ Refers to species considered "near threatened" and above by [43] (except for Q. semecarpifolia and Q. accutissima, non-assessed by IUCN, information was obtained in [37]) 


\section{Cryopreservation}

Cryopreservation is recognised as the only option for the long-term banking of all plant species [11]. The cryobiotechnological approach (as defined by [45]) depends on the determination of the natural level of stress tolerance, combined with a mechanistic understanding of survival stability and the implementation of appropriate protocols. Necessarily, cryobiotechnology is demanding and precise and a single option is not always available for each tissue. Thus, scientific and wide-scale-implementation challenges must be faced [11,18,19]. In this section we reviewed the main tissues of Quercus sp. that can be cryopreserved, the main approaches used and their associated challenges. Tissues are presented in order of tissue complexity, from pollen to embryos and embryonic axes.

\subsection{Pollen}

Whilst the seeds of Quercus sp. are desiccation sensitive and require cryopreservation of their axes for long-term storage (see Section 5.6), the pollen seems to have much greater drying tolerance $[46,47]$. This indicates that the pollen could be routinely dried and preserved at low temperatures with relatively simple methods, akin to those used for conventional seed banking. For example, $Q$. coccinea and $Q$. alba pollen survived for at least a year when dried at $25-35 \% \mathrm{RH}$ and stored at $2{ }^{\circ} \mathrm{C}[46,48]$, germinability of dry pollen of $Q$. robur was preserved up to two years at $-20^{\circ} \mathrm{C}$ [49], dry pollen of $Q$. petraea and $Q$. robur was stored for at least 1 year at $-18^{\circ} \mathrm{C}$ and used in breeding programmes for acorn production [50], and freeze-dried pollen retained some viability after 300 days at $-5{ }^{\circ} \mathrm{C}$ [46]. The pollen of some Quercus sp. is also known to tolerate cryopreservation; for example, Q. petraea and Q. robur pollen had high survival after exposure to LN [51].

Pollen can retain viability for at least 10-15 years (and potentially for decades) when stored at LN temperatures as reported for diverse agricultural and ornamental species [52-54]. Therefore, cryopreservation of pollen could be used as a complementary technology to support conservation and breeding programmes of Quercus sp., as currently implemented for diverse fruit tree species [12,16]. For example, pollen preservation is a useful tool when researching and implementing disease resistance breeding in diverse threatened species within Fagaceae (the oak family). For instance, pollen preserved dry at $4{ }^{\circ} \mathrm{C}$ was the source for controlled cross-pollinations with extant American beech trees that are resistant to beech bark disease [55]. Furthermore, long term cryopreservation of pollen can play a vital role when resurrecting genotypes that have been lost to disease, as it was the case of Castanea dentata trees, which pollen was stored for over 20 years in LN and successfully used to produce seeds in extant American chestnut trees [11].

Pollen viability after preservation experiments is often tested with in vitro germination assays that test the ability of pollen to produce and elongate the pollen tube. The levels of nutrients, sucrose and agar influence pollen germination and need to be determined and adjusted per species. In the case of Quercus sp., pollen germination media usually contains 10-20\% sucrose and is often solidified with $0.75-1 \%$ agar $([48,49,51,56]$ for $Q$. coccinea, $Q$. petraea and $Q$. robur $)$. Sometimes mineral nutrients have been added to the basic sucrose solutions, such as 20 ppm boron for Q. alba, Q. coccinea, and Q. ilicifolia [46] or MS salts for Q. robur [56].

\subsection{Embryogenic Calli and Somatic Embryos}

Somatic embryogenesis is a powerful tool for conservation of forest trees. It is considered to be the most appropriate means of in vitro regeneration of woody plants and may be the only method of regenerating truly juvenile propagules of difficult-to-propagate species (reviewed in [14] for Quercus sp.). Cryopreservation of somatic embryos of $Q$. robur and $Q$. suber [57-59], embryogenic lines initiated from mature selected trees of $Q$. suber [60], and embryogenic tissues from mature Q. ilex [61] has been studied and developed. All these approaches allowed the regeneration of whole plants, regardless of the method used. However, research may be needed to optimize and increase the differentiation ability of the cryopreserved embryogenic lines in some species (e.g., [61]). 
Cryopreservation is routinely applied to embryogenic lines of some conifers [62] and the first approaches undertaken on the application of cryopreservation to hardwood forest tree species $[63,64]$. In addition, the feasibility of constructing a large cryo-bank for cork oak (Q. suber) genotypes has been proposed on the basis of the successful proliferation of 51 embryogenic lines after immersion in LN [14]. Research to determine the field productivity and heritable characters of the recovered is ongoing [64]. These pioneer studies have laid the groundwork for the development of large-scale propagation and cryopreservation initiatives of threatened woody species for which micropropagation procedures have already been developed (Table 1).

\subsection{Shoot Tips}

Shoot tips grown in vitro are a common source of plant material for the cryopreservation of plant species of interest for agriculture [16,44], forestry [64] and conservation, including threatened species [65]. It appears there is only one report on the successful cryopreservation of Quercus species' shoot tips [39]. The shoot tips cultures used were initiated from either seedlings ( $Q$. virginiana and Q. suber) or shoot cuttings of new growth (Q. gambelii and Q. hinckleyii). Q. virginiana shoot tips had the best survival level (56\%), compared with Q. hinckleyi (20\%), Q. suber (12\%) and Q. gambelii (0\%) [39]. Considering the wide range of Quercus species for which shoot tip cultures can be initiative (Table 1), these results significantly expand the options for ex situ conservation of the threatened species within this genus. Further research on a wider range of species and on the in vitro conditions necessary for the rooting of shoot tips is necessary as part of the implementation of cryobiotechnology programs for oak conservation.

\subsection{Plumules}

The cryopreservation of oak germplasm as plumules (i.e., shoot apical meristems of embryos) may offer a potential approach for the conservation in gene banks of some Quercus sp., particularly when the cryopreservation of the whole embryo is challenging [35]. This is a promising approach for two reasons: (1) the plumule has a great potential for the development of a whole plant in vitro in contrast to the root axes $[35,66,67]$; and (2) high genetic diversity could be stored from a population by excising the plumules of the embryos of individual seeds, similarly to that achieved by preserving the whole seed or the embryo axes. Cryopreservation of plumules has been performed routinely on Q. robur and Q. petraea at the Kostrzyca Forest Gene Bank, Poland [68]. Regrowth is between 8 and $20 \%$, suggesting the need to optimize further the cryobiotechnology protocols [35].

\subsection{Dormant Buds}

For woody species of temperate regions, there is the option of cryopreserving vegetative buds, particularly dormant buds after their natural adaptation to cold conditions. This approach has been used for the large-scale cryopreservation of many woody crop species, such as apple, pear, mulberry, sour cherry, silver birch, aspen, willow and persimmon (reviewed in $[16,69]$ ). Briefly, dormant buds are harvested from the field in mid-winter, and after partial desiccation (if needed) to $25-41 \%$ moisture content, depending on species, they are usually cooled in a two-steps: controlled, relatively slow cooling to -30 or $-40{ }^{\circ} \mathrm{C}$; followed by transfer to $\mathrm{LN}$ or $\mathrm{LN}$ vapour. The rate of control cooling depends on the species, and sometimes the use of cryoprotectants is needed. Dormant buds are later recovered by direct grafting of the bud on the tree, micrografting of the dissected shoot tip, micropropagation of the bud or the dissected shoot tip or direct rooting of the cryopreserved branch section, depending on the species [69]. Cryopreservation of dormant vegetative buds depends on the cold-hardiness level of the collected material. Hence, the level of cold acclimation that the species can attain and the extent of acclimation that the material possesses when collection are the most critical factors for success $[16,69]$.

Cryopreservation of oak dormant buds could be a very valuable approach to explore based on success with other forestry species, including Juglans cinerea, Ulmus sp., Populus sp., Salix sp. and Pinus sylvestris [69-71]. Many Quercus sp. inhabit very cold environments, and these could be good 
candidates for dormant buds' cryopreservation [69]. For example, mean cold hardiness values in December-January are about $-56,-45$ and $-27^{\circ} \mathrm{C}$ for European Q. robur, Q. pubescens and Q. ilex, respectively [72], and between -30 and $-50{ }^{\circ} \mathrm{C}$ for Q. rubra from diverse US provenances [73]. Twelve other Quercus sp. grown in the US (Q. acutissima, Q. alba, Q. bicolor, Q. coccinea, Q. imbricaria, Q. macrocarpa, Q. montana, Q. muehlenbergii, Q. palustris, Q. phellos, Q. shumardii and Q. velutina) can tolerate winter temperatures between -20 and $-40{ }^{\circ} \mathrm{C}$ [74]. For comparison, Malus sp., a genus for which dormant buds' cryopreservation is quite successful, are considered "quite cold hardy" [69]. For example, dormant buds' cryopreservation with $>60 \%$ regrowth is known for trees with cold hardiness values around $-12{ }^{\circ} \mathrm{C}$ to $-15^{\circ} \mathrm{C}$ (e.g., M. domestica and M. sieversii [75]). Similarly, species native to areas with winter lower temperatures below $-15{ }^{\circ} \mathrm{C}$ (e.g., M. ioensis from Central North America and M. coronaria from NE North America [76]) are amenable to cryopreservation.

In terms of explant recovery and growth after cryopreservation, one of the requirements is the availability of suitable micropropagation or grafting protocols. Importantly, micropropagation protocols have been developed already for dormant buds of Q. alba, Q. bicolor, Q. cerris, Q. falcata, Q. imbricaria, $Q$. macrocarpa, Q. pagoda, Q. palustris, Q. robur, Q. rubra, Q. texana, Q. variabilis and Q. virgiliana [77-79]. Grafting of Quercus species is a common horticulture practice [80,81], and micrografting has been successfully used, for example, on Q. robur [82].

However, to our knowledge, cryopreservation of dormant vegetative buds has not been properly explored for Quercus sp. Yet, although pilot studies have been implemented in a few species [83].

\subsection{Seed Embryos}

Seed embryonic axes or zygotic embryos (i.e., explants with both shoot and root meristems) are the preferred explants for the ex situ conservation of recalcitrant seeds [84,85], as they can be grown into full plants with relatively simple micropropagation procedures and its preservation could capture high genetic diversity (similarly to that captured with whole seed storage) [11]. Cryopreservation has been attempted in about 16 species of oaks (summarized in Table 2). Success has been relatively low, with only four species (Q. faginea, Q. gambellii, Q. rubra and Q. schottkyana) showing root and shoot recovery (5-60\%) after exposure to liquid nitrogen. High ( $>60 \%)$ explant survival (i.e., axes expanded, greened, formed callus or showed normal development of roots or shoots) was found in only six of the species tested. Most species showing good survival and plantlet growth were dried from initial water contents of $>1 \mathrm{gH}_{2} \mathrm{O} \mathrm{g}^{-1} \mathrm{DW}(>50 \% \mathrm{FWB})$ to between 0.27 and $0.40 \mathrm{gH}_{2} \mathrm{O} \mathrm{g}^{-1} \mathrm{DW}(21-29 \% \mathrm{FWB})$, except for $Q$. gambellii that tolerated drying down to $0.10 \mathrm{gH}_{2} \mathrm{O} \mathrm{g}^{-1} \mathrm{DW}(9 \% \mathrm{FWB}$; Table 2). In addition, all species showing good survival and plantlet growth, were cooled and warmed relatively fast, with cooling rates above $3^{\circ} \mathrm{C} \mathrm{s}^{-1}$ (Table 2). WPM was the recovery media used in all species showing good survival and plantlet growth (Table 2). 
Table 2. Cryopreservation successes with embryonic axes of Quercus sp.

\begin{tabular}{|c|c|c|c|c|c|c|c|c|c|}
\hline Species \# & Desiccation & $\begin{array}{c}\text { Moisture Content }^{1} \\
(\% \mathrm{FWB}) \\
{\left[\left(\mathrm{gH}_{2} \mathrm{O} / \mathrm{gDW}\right)\right]}\end{array}$ & Cooling & Warming & $\begin{array}{l}\text { Basic Salts and } \\
\text { Organics }^{2}\end{array}$ & $\begin{array}{l}\text { Plant Growth } \\
\text { Regulators }\end{array}$ & $\begin{array}{c}\text { Survival }^{3} \\
(\%)\end{array}$ & Plantlet Formation ${ }^{4}(\%)$ & Reference \\
\hline Q. alba L. & $\begin{array}{l}\text { air stream (laminar } \\
\text { flow hood) }\end{array}$ & N/A & $\begin{array}{l}\text { in aluminium foil packet } \\
\text { or cryovials, submerged } \\
\text { into LN. }\end{array}$ & $\begin{array}{l}\text { ambient temperature } \\
\text { (20 min) }\end{array}$ & MS & $\begin{array}{c}2 \mathrm{mg} / \mathrm{L} \mathrm{BAP}+ \\
2 \mathrm{mg} / \mathrm{mL} \text { IAPhe }\end{array}$ & 25 & 0 & [86] \\
\hline Q. faginea $\mathrm{Lam}$. & $\begin{array}{l}\text { air stream (laminar } \\
\text { flow hood) }\end{array}$ & $\begin{array}{c}21 \% \\
{[0.27]}\end{array}$ & $\begin{array}{l}\text { in cryovials and } \\
\text { submerged into LN }\end{array}$ & $40^{\circ} \mathrm{C}$ water bath $(1 \mathrm{~min})$ & $\begin{array}{l}\text { WPM + MS } \\
\text { vitamins }\end{array}$ & $1.5 \mathrm{mg} / \mathrm{L} \mathrm{BAP}$ & 75 & $60^{\mathrm{a}}$ & [87] \\
\hline Q. falcata Michx. & $\begin{array}{l}\text { air stream (laminar } \\
\text { flow hood) }\end{array}$ & $\begin{array}{c}36 \% \\
{[0.56]}\end{array}$ & $\begin{array}{l}\text { in cryovials and } \\
\text { submerged into LN }\end{array}$ & $\begin{array}{c}\text { ambient temperature } \\
\text { (20 min) }\end{array}$ & MS & $\begin{array}{l}2 \mathrm{mg} / \mathrm{L} \mathrm{BAP}+ \\
2 \mathrm{mg} / \mathrm{mL} \text { IAPhe }\end{array}$ & 65 & 0 & [88] \\
\hline Q. franchetii Skan & Flash drying 2 & diverse MC & diverse cooling rates & $\begin{array}{l}\text { axes immersed in } 0.5 \mathrm{M} \\
\text { sucrose heated to } 42^{\circ} \mathrm{C}\end{array}$ & $\begin{array}{l}\text { WPM with } 0.3 \% \\
\text { charcoal }\end{array}$ & none & 0 & 0 & [36] \\
\hline Q. gambelii * Liebm. & Flash drying 2 & $\begin{array}{l}38 \% \\
{[0.6]}\end{array}$ & $\begin{array}{l}\text { in cryovials and } \\
\text { submerged into LN (3-8 } \\
\left.{ }^{\circ} \mathrm{C} \mathrm{s}^{-1}\right)\end{array}$ & $\begin{array}{l}\text { axes immersed in } 0.5 \mathrm{M} \\
\text { sucrose heated to } 42^{\circ} \mathrm{C}\end{array}$ & $\begin{array}{l}\text { WPM with } 0.3 \% \\
\text { charcoal }\end{array}$ & none & 60 & 0 & [36] \\
\hline Q. gambelii ** Liebm. & Flash drying 2 & $\begin{array}{c}9 \% \\
{[0.1]}\end{array}$ & $\begin{array}{l}\text { in aluminium foil packets } \\
\text { and plunged into } \mathrm{N}_{2} \\
\text { slush }\left(30-800^{\circ} \mathrm{C} \mathrm{s}^{-1}\right)\end{array}$ & $\begin{array}{l}\text { axes immersed in } 0.5 \mathrm{M} \\
\text { sucrose heated to } 42^{\circ} \mathrm{C}\end{array}$ & $\begin{array}{l}\text { WPM with } 0.3 \% \\
\text { charcoal }\end{array}$ & none & 90 & $3 \%$ & [36] \\
\hline Q. gambelii ** Liebm. & Flash drying 2 & $\begin{array}{l}17 \% \\
{[0.2]}\end{array}$ & $\begin{array}{l}\text { in cryovials and } \\
\text { submerged into LN (3-8 } \\
\left.{ }^{\circ} \mathrm{C} \mathrm{s}^{-1}\right)\end{array}$ & $\begin{array}{l}\text { axes immersed in } 0.5 \mathrm{M} \\
\text { sucrose heated to } 42^{\circ} \mathrm{C}\end{array}$ & $\begin{array}{l}\text { WPM with } 0.3 \% \\
\text { charcoal }\end{array}$ & none & 90 & $3 \%$ & [36] \\
\hline Q. ilex $\mathrm{L}$. & $\begin{array}{l}\text { air stream (laminar } \\
\text { flow hood) }\end{array}$ & $\begin{array}{c}13 \% \\
{[0.15]}\end{array}$ & $\begin{array}{l}\text { in cryovials and } \\
\text { submerged into LN }\end{array}$ & $40^{\circ} \mathrm{C}$ water bath $(1 \mathrm{~min})$ & WPM & $0.1 \mathrm{mg} / \mathrm{L} \mathrm{BA}$ & 85 & $0^{\mathrm{b}}$ & [33] \\
\hline Q. ilex $\mathrm{L}$. & $\begin{array}{l}\text { air stream (laminar } \\
\text { flow hood) }\end{array}$ & $\begin{array}{c}18 \% \\
{[0.22]}\end{array}$ & $\begin{array}{l}\text { in plastic mesh bags and } \\
\text { immersed in sub-cooled } \\
\text { LN. }\end{array}$ & $\begin{array}{l}\text { In WPM liquid medium } \\
\text { at room temperature. }\end{array}$ & WPM & $1 \mathrm{mg} / \mathrm{L}$ BA & 94 & $0^{\mathrm{b}}$ & [33] \\
\hline $\begin{array}{l}\text { Q. leucotrichophora ex } \\
\text { Bahadur (syn of } Q \text {. } \\
\text { oblongata D.Don) }\end{array}$ & $\begin{array}{l}\text { air stream (laminar } \\
\text { flow hood) }\end{array}$ & $\begin{array}{c}13-14 \% \\
{[0.15-0.16]}\end{array}$ & $\begin{array}{l}\text { in cryovials and } \\
\text { submerged into LN }\end{array}$ & $37^{\circ} \mathrm{C}$ water bath $(15 \mathrm{~min})$ & $\begin{array}{c}\mathrm{MS}+0.17 \mathrm{~g} / \mathrm{L} \\
\mathrm{NaH}_{2} \mathrm{PO}_{4}+2 \mathrm{~g} / \mathrm{L} \\
\text { charcoal }\end{array}$ & $\begin{array}{c}1 \mathrm{mg} / \mathrm{L} \mathrm{NAA} \text { or } \\
\mathrm{IAA}+1 \mathrm{mg} / \mathrm{L} \\
\text { Kinetin, BAP or } \\
2 \mathrm{iP}\end{array}$ & $15-25$ & Non available & [89] \\
\hline Q. macrocarpa Michx. & $\begin{array}{l}\text { air stream (laminar } \\
\text { flow hood) }\end{array}$ & N/A & $\begin{array}{l}\text { in aluminium foil packet } \\
\text { or cryovials, submerged } \\
\text { into LN. }\end{array}$ & $\begin{array}{l}\text { ambient temperature } \\
(20 \mathrm{~min})\end{array}$ & MS & $\begin{array}{l}2 \mathrm{mg} / \mathrm{L} \mathrm{BAP}+2 \\
\mathrm{mg} / \mathrm{mL} \text { IAPhe }\end{array}$ & 20 & 0 & [86] \\
\hline Q. macrocarpa Michx. & $\begin{array}{l}\text { air stream (laminar } \\
\text { flow hood) }\end{array}$ & $\begin{array}{c}36 \% \\
{[0.56]}\end{array}$ & $\begin{array}{l}\text { in cryovials and } \\
\text { submerged into LN }\end{array}$ & $\begin{array}{l}\text { ambient temperature } \\
\text { (20 min) }\end{array}$ & MS & $\begin{array}{l}2 \mathrm{mg} / \mathrm{L} \mathrm{BAP}+2 \\
\mathrm{mg} / \mathrm{mL} \text { IAPhe }\end{array}$ & N/A & 0 & [88] \\
\hline $\begin{array}{l}\text { Q. marilandica (L.) } \\
\text { Müncch. }\end{array}$ & $\begin{array}{l}\text { air stream (laminar } \\
\text { flow hood) }\end{array}$ & N/A & $\begin{array}{l}\text { in aluminium foil packet } \\
\text { or cryovials, submerged } \\
\text { into LN. }\end{array}$ & $\begin{array}{l}\text { ambient temperature } \\
\text { (20 } \mathrm{min})\end{array}$ & MS & $\begin{array}{l}2 \mathrm{mg} / \mathrm{L} \mathrm{BAP}+2 \\
\mathrm{mg} / \mathrm{mL} \text { IAPhe }\end{array}$ & 0 & 0 & [86] \\
\hline $\begin{array}{l}\text { Q. muhlembergii } \\
\text { Engelm. }\end{array}$ & $\begin{array}{l}\text { air stream (laminar } \\
\text { flow hood) }\end{array}$ & $\mathrm{N} / \mathrm{A}$ & $\begin{array}{l}\text { in aluminium foil packet } \\
\text { or cryovials, submerged } \\
\text { into LN. }\end{array}$ & $\begin{array}{l}\text { ambient temperature } \\
\text { (20 min) }\end{array}$ & MS & $\begin{array}{c}2 \mathrm{mg} / \mathrm{L} \mathrm{BAP}+2 \\
\mathrm{mg} / \mathrm{mL} \text { IAPhe }\end{array}$ & 40 & 0 & [86] \\
\hline Q. nigra L. & $\begin{array}{l}\text { air stream (laminar } \\
\text { flow hood) }\end{array}$ & $\begin{array}{c}25 \% \\
{[0.33]}\end{array}$ & $\begin{array}{l}\text { in cryovials and } \\
\text { submerged into LN }\end{array}$ & $\begin{array}{l}\text { ambient temperature } \\
(20 \mathrm{~min})\end{array}$ & MS & $\begin{array}{c}2 \mathrm{mg} / \mathrm{L} \mathrm{BAP}+2 \\
\mathrm{mg} / \mathrm{mL} \text { IAPhe }\end{array}$ & 50 & 0 & [88] \\
\hline $\begin{array}{l}\text { Q. palustris Regel ex } \\
\text { A.DC. (syn Q. coccinea } \\
\text { Münchh) }\end{array}$ & $\begin{array}{l}\text { air stream (laminar } \\
\text { flow hood) }\end{array}$ & $\begin{array}{c}20 \% \\
{[0.25]}\end{array}$ & $\begin{array}{l}\text { in cryovials and } \\
\text { submerged into LN }\end{array}$ & $\begin{array}{l}\text { ambient temperature } \\
(20 \mathrm{~min})\end{array}$ & MS & $\begin{array}{c}2 \mathrm{mg} / \mathrm{L} \mathrm{BAP}+2 \\
\mathrm{mg} / \mathrm{mL} \text { IAPhe }\end{array}$ & 12 & 0 & [88] \\
\hline Q. robur $\mathrm{L}$. & Flash drying 1 & $\begin{array}{c}21 \% \\
{[0.27]}\end{array}$ & $\begin{array}{l}\text { 'naked' axes plunged into } \\
\text { isopentane held in a } \\
\text { LN reservoir. }\end{array}$ & $\begin{array}{l}\text { axes immersed in } \\
\text { solution containing } \mathrm{Ca} 2+ \\
\text { and } \mathrm{Mg} 2+\end{array}$ & N/A & N/A & 100 & $0^{d}$ & [90] \\
\hline
\end{tabular}


Table 2. Cont.

\begin{tabular}{|c|c|c|c|c|c|c|c|c|c|}
\hline Species \# & Desiccation & $\begin{array}{c}\text { Moisture Content }^{1} \\
(\% \mathrm{FWB}) \\
{\left[\left(\mathrm{gH}_{2} \mathrm{O} / \mathrm{gDW}\right)\right]}\end{array}$ & Cooling & Warming & $\begin{array}{l}\text { Basic Salts and } \\
\text { Organics }{ }^{2}\end{array}$ & $\begin{array}{l}\text { Plant Growth } \\
\text { Regulators }\end{array}$ & $\begin{array}{c}\text { Survival }^{3} \\
(\%)\end{array}$ & Plantlet Formation ${ }^{4}(\%)$ & Reference \\
\hline Q. rubra $\mathrm{L}$. & $\begin{array}{l}\text { air stream (laminar } \\
\text { flow hood) }\end{array}$ & $\begin{array}{c}20 \% \\
{[0.25]}\end{array}$ & $\begin{array}{c}\text { in cryovials and } \\
\text { submerged into LN }\end{array}$ & $\begin{array}{l}\text { ambient temperature } \\
(20 \mathrm{~min})\end{array}$ & MS & $\begin{array}{c}2 \mathrm{mg} / \mathrm{L} \mathrm{BAP}+2 \\
\mathrm{mg} / \mathrm{mL} \text { IAPhe }\end{array}$ & 85 & 0 & [88] \\
\hline Q. rubra $\mathrm{L}$. & Flash drying 2 & $\begin{array}{l}23 \% \\
{[0.3]}\end{array}$ & $\begin{array}{l}\text { in aluminium foil packets } \\
\text { and plunged into } \mathrm{N}_{2} \\
\text { slush }\left(30-80^{\circ} \mathrm{C} \mathrm{s}^{-1}\right)\end{array}$ & $\begin{array}{l}\text { axes immersed in } 0.5 \mathrm{M} \\
\text { sucrose heated to } 42^{\circ} \mathrm{C}\end{array}$ & $\begin{array}{l}\text { WPM with } 0.3 \% \\
\text { charcoal }\end{array}$ & none & 90 & 60 & {$[36]$} \\
\hline Q. rubra $\mathrm{L}$. & Flash drying 2 & $\begin{array}{l}23 \% \\
{[0.3]}\end{array}$ & $\begin{array}{c}\text { in cryovials and } \\
\text { submerged into LN (3-8 } \\
\left.{ }^{\circ} \mathrm{C} \mathrm{s}^{-1}\right)\end{array}$ & $\begin{array}{l}\text { axes immersed in } 0.5 \mathrm{M} \\
\text { sucrose heated to } 42^{\circ} \mathrm{C}\end{array}$ & $\begin{array}{l}\text { WPM with } 0.3 \% \\
\text { charcoal }\end{array}$ & none & 90 & 40 & {$[36]$} \\
\hline $\begin{array}{l}\text { Q. schottkyana Rehder } \\
\text { and E.H. Wilson }\end{array}$ & Flash drying 2 & $\begin{array}{l}29 \% \\
{[0.4]}\end{array}$ & $\begin{array}{l}\text { in cryovials and } \\
\text { submerged into LN (3-8 } \\
\left.{ }^{\circ} \mathrm{C} \mathrm{s}^{-1}\right)\end{array}$ & $\begin{array}{l}\text { axes immersed in } 0.5 \mathrm{M} \\
\text { sucrose heated to } 42^{\circ} \mathrm{C}\end{array}$ & $\begin{array}{l}\text { WPM with } 0.3 \% \\
\text { charcoal }\end{array}$ & none & 30 & 5 & [36] \\
\hline Q. suber $\mathrm{L}$. & $\begin{array}{l}\text { air stream (laminar } \\
\text { flow hood) }\end{array}$ & $\begin{array}{c}18 \% \\
{[0.22]}\end{array}$ & $\begin{array}{l}\text { in cryovials and } \\
\text { submerged into LN }\end{array}$ & $40^{\circ} \mathrm{C}$ water bath $(1 \mathrm{~min})$ & WPM & $0.1 \mathrm{mg} / \mathrm{L} \mathrm{BA}$ & 30 & $0^{\mathrm{c}}$ & [33] \\
\hline
\end{tabular}

\# Names authorities follow [42]. * from a population collected in Nevada, USA; ** from a population collected in Wyoming, USA. Flash drying 1: computer fan and silica-gel device; Flash drying 2: axes rapidly dried over a stream of nitrogen gas (technical specifications can be found in [91]). ${ }^{1}$ when moisture contents were available only in fresh weight basis (FWB) or dry weight basis (DWB), the following formula was used to calculate moisture content: $\mathrm{FWB}=\mathrm{DWB} /(\mathrm{DWB}+1)[92]{ }^{2}$ all media enriched with $3 \%$ sucrose and generally solidified with $0.8 \%$ agar; ${ }^{3}$ axes had expanded, greened, formed callus or showed normal development of roots and shoots; ${ }^{4}$ normal development of roots and shoots (often considered as doubling of radicle length or greening of shoots). BAP: 6-benzylaminopurine; BA: N6-benzyladenine; IAPhe: indoleacetylphenylalanine. ${ }^{\text {a }}$ plants showing normal development of roots and shoots or only shoots; ${ }^{\mathrm{b}} 15 \%$ shoot development (no plantlet); ${ }^{\mathrm{c}} 5 \%$ shoot development (no plantlet); ${ }^{\mathrm{d}} 70 \%$ organised shoot development after a few days (no actual growth measured in vitro). 


\section{Challenges in Oak Cryobiotechnology}

Plant cryobiotechnology has a relatively recent past and a favourable present [15,45]. However, plant cryobiotechnology does not consist simply of plunging plant tissues into LN and growing them after melting, i.e., cryopreservation. Rather, cryobiotechnology provides a conceptual framework for the integration of thinking about the evolution of and natural adaptation to low temperatures with advances in fundamental understanding of stress tolerance and survival, and the design of enabling cryopreservation techniques and infrastructure [45]. Only by integrating these components of cryobiotechnology will it be possible for the preservation of tissues of all plant species to become a reality [11]. In this section we explored some of the research challenges associated with two aspects of cryobiotechnology: embryonic axis cryopreservation and in vitro plant growth.

\subsection{Cryobiotechnology of Embryonic Axes and Zygotic Embryos}

Cryopreservation of embryonic axes and zygotic embryos of recalcitrant seeds can be limited by different responses between species and populations to desiccation and LN exposure, physical damage to the embryo during isolation, oxidative stress associated to excision and cryopreservation procedures, differential stress tolerances of shoot and root meristems and the need to improve in vitro growth and acclimation procedures (e.g., Table 3). Many of these challenges have been investigated for Quercus sp. (references highlighted in bold letters in Table 3) and the findings translated into some cryopreservation successes. Indeed, three out of the four oak species for which shoot and root growth have been obtained (Q. gambellii, Q. rubra and Q. schottkyana; [36]) were cryopreserved after the application of three cryobiotechnological advances pioneered by $[86,88]$. These advances include the application of antioxidants during axis excision and the use of fast ("flash") drying and cooling procedures (Table 3, [36]). 
Table 3. Research challenges and innovations in the cryopreservation of embryonic axes and zygotic embryos of recalcitrant seeds. References in bold indicate that the work is related to Quercus sp.

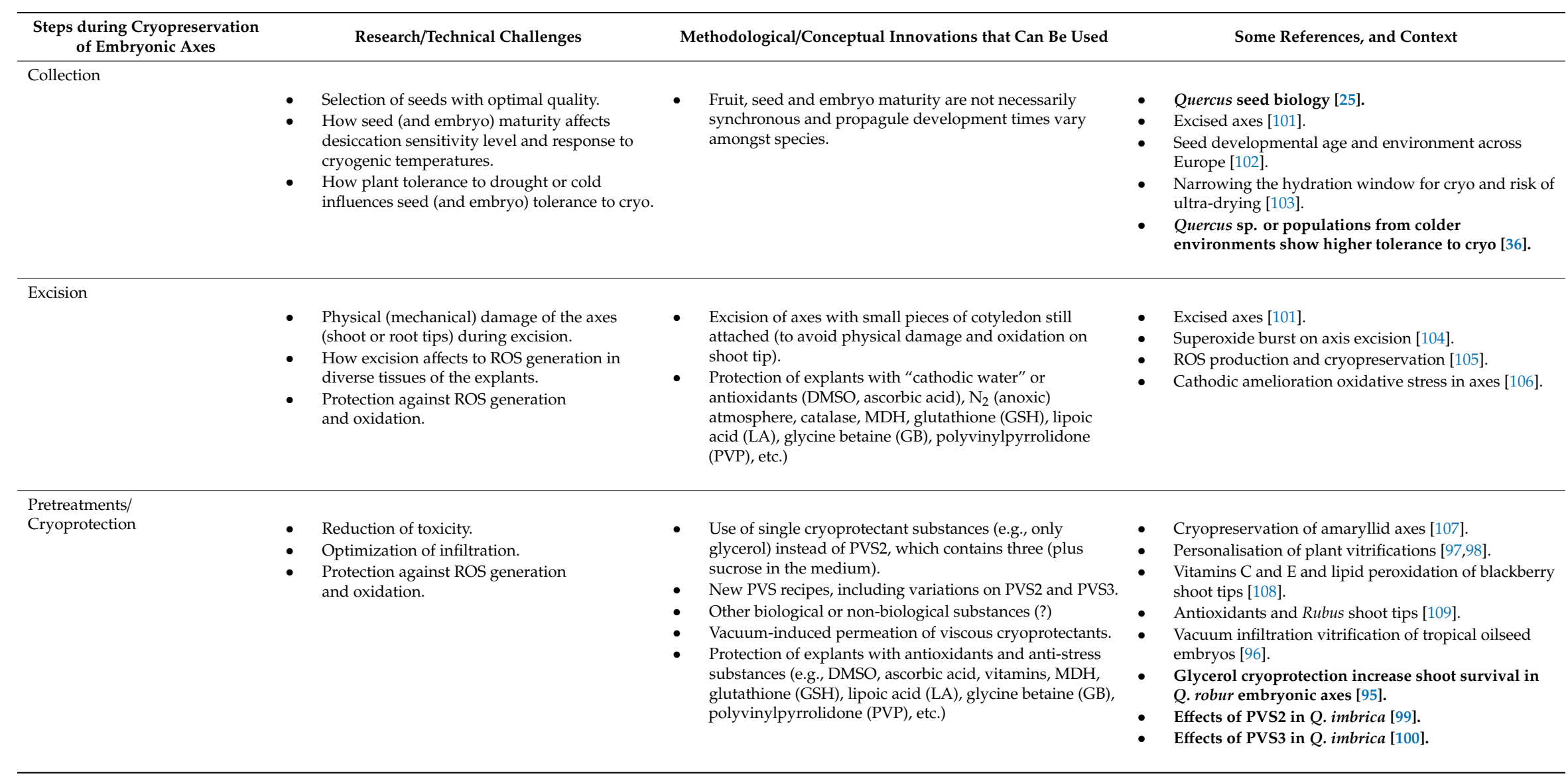


Table 3. Cont.

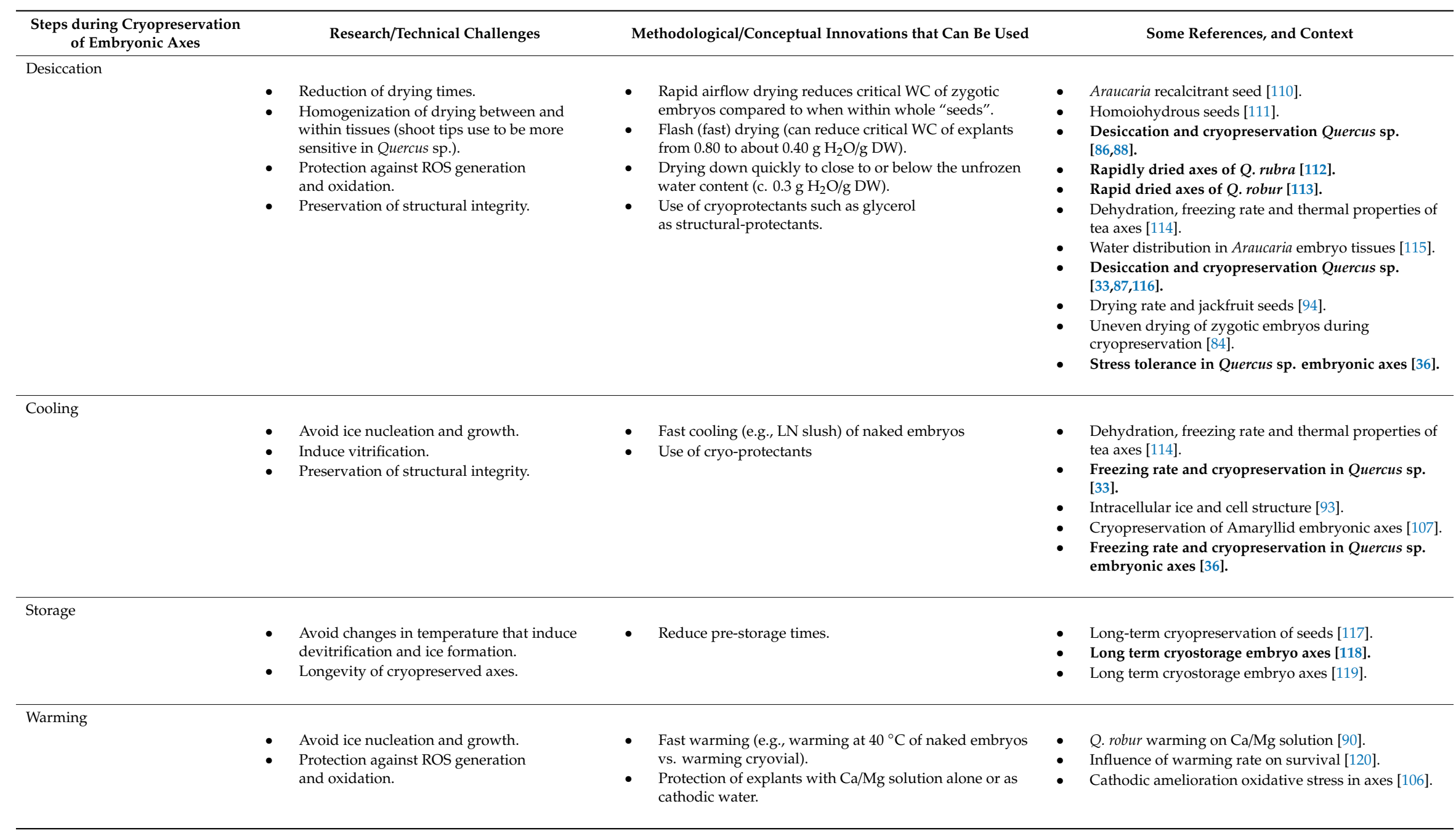


Table 3. Cont

\begin{tabular}{|c|c|c|c|}
\hline $\begin{array}{c}\text { Steps during Cryopreservation } \\
\text { of Embryonic Axes }\end{array}$ & Research/Technical Challenges & Methodological/Conceptual Innovations that Can Be Used & Some References, and Context \\
\hline $\begin{array}{l}\text { Regeneration/ } \\
\text { In vitro culture }\end{array}$ & $\begin{array}{l}\text { - Culture media (mineral and hormone } \\
\text { composition). } \\
\text { - Culture conditions (light and temperature). }\end{array}$ & $\begin{array}{l}\text { Design of Experiments (DOE) approach to find optimal } \\
\text { nutrient composition. } \\
\text { - Initial recovery in dark conditions to } \\
\text { avoid photo-oxidation. }\end{array}$ & $\begin{array}{l}\text { - Design of Experiments (DOE) approach for plant } \\
\text { in vitro culture [121]. } \\
\text { - Quercus in vitro after cryo [33]. } \\
\text { - DOE Quercus in vitro growth [122]. }\end{array}$ \\
\hline Plant growth and acclimation & $\begin{array}{l}\text { - Acclimation. } \\
\text { - Tolerance to stress of acclimated plants. }\end{array}$ & $\begin{array}{l}\text { - } \quad \text { Venting lids. } \\
\text { - } \quad \text { Dettom cooling. } \\
\text { - }\end{array}$ & $\begin{array}{l}\text { - } \quad \text { Quercus sp. acclimation from in vitro [123]. } \\
\text { - } \quad \text { Quercuation of plantlets to ex vitro conditions [124]. } \\
\text { - Stress tolerance of acclimated from in vitro [125]. } \\
\text { cryopreservation [126]. }\end{array}$ \\
\hline
\end{tabular}


The general low success in oak embryonic axes cryopreservation (Table 2) in early works could be related to the methods then available and practiced. For example, all (eight) species studied by Pence $[86,88]$ were thawed slowly at ambient temperature for $20 \mathrm{~min}$ (Table 2). This slow thawing in axes containing water contents $>0.20 \mathrm{~g} \mathrm{H}_{2} \mathrm{O} / \mathrm{g}$ dry weight (Table 2) could have enabled lethal ice formation during thawing (Table 3 [3]), reducing overall survival. In addition, embryos of most species used by Pence [88] were cooled relatively slowly within cryovials (Table 2), whereas there is more recent evidence that faster cooling (and warming) is beneficial for the survival and growth of recalcitrant seed embryo axes, including those of oak species (Table 3, [36,93]). Furthermore, greatest success after cryopreservation has been obtained in oak species when dried very fast, i.e., "flash drying" (Table 3, [94]) [36], which was not the drying method used in early works (Table 2).

However, the low success in oak embryonic axes cryopreservation (see Section 5.6, Table 2) could also have been due to the natural sensitivity of the axes of the different oak species to the stresses of partial desiccation and LN exposure [36] in relation to the species' environmental cues. This seems to contribute to both inter- and intraspecific variability in success (Table 3, [36]), and might, in future, be used to better predict species/populations responses. With this in mind, we are studying the cryopreservation of 12 oak species from diverse provenances in Europe and the Mediterranean region. In our protocol [91] we are using antioxidants at the collection of excised embryos, a flash drying method, a range of fast cooling rates and fast warming. We observed the relatively successful cryopreservation of Q. ilex, Q. coccifera and Q. pyrenaica, with root and shoot recovery around $25 \%$ and $50 \%$ for $Q$. ilex and $Q$. pyrenaica, respectively [95]. These results raise the overall success of oak embryonic axis cryopreservation from four to seven species, just by improving the cryobiotechnology approach (Table 3). Our interests extend to innovations around cryoprotection, e.g., using vacuum infiltration vitrification [96] and the development of bespoke cryoprotectant mixtures $[97,98]$. Our overall aim is to generate accurate predictive tools for the optimal application of cryopreservation methods to a wide range of oak species from in the world. We are not alone in this ambition $[36,99,100]$ and anticipate greater opportunities for a global collaborative effort in the future.

\subsection{Overcoming Challenges of In Vitro Plant Growth}

In vitro growth after cryopreservation of embryo axes of several recalcitrant seeded species from tropical and temperate origin has been performed generally on media without plant growth regulators $[36,93,94,106,127,128]$. However, the presence of some growth regulators, such as 6-benzyladenine (BAP), may favour shoot development after cryopreservation in some Quercus, and other, species of temperate origin (e.g., $[33,89,129]$, Table 3). These contrasting results suggest that more research is needed to ascertain the positive, neutral or negative role of plant growth regulators on the recovery of embryo axes after cryopreservation.

Vanhove et al. [122] have provided guidance for an improved medium for the recovery of Q. palustris embryonic axes pre-cryo, i.e., a control mainly subjected to excision stress. However, it is possible that the optimal conditions for axes growth pre- and post-cryo (i.e., subjected to excision, desiccation and low temperature stresses) are not the same $[93,130]$. Clearly, improvements are needed to help overcome the low success of shoot growth from cryopreserved embryo axes (Table 3).

One challenge for the optimisation of media for in vitro plant growth or organogenesis from embryo axes, pre- and post-cryo, is the seemingly infinite number of potential phytohormone combinations, generally resolved through rigorous research [66]. Other factor combinations (e.g., diverse salts and $\mathrm{pH}$ ) might also be important and interact [121]. Vanhove et al. [122] addressed this challenge using the DOE (design of experiments) approach. Design of Experiments (DOE) is a statistical approach to determine the relationship between factors affecting a process and the output of that process. DOE is much more rigorous than traditional methods of experimentation such as one-factor-at-a-time and expert trial-and-error. This rigour allows researchers to model the relationships among the numerous variables in a system and reach better solutions sooner, without using a fully factorial design. For example, of the six factors tested $\left(\mathrm{NO}_{3}, \mathrm{PO}_{4}, \mathrm{BAP}, \mathrm{IAA}, \mathrm{MS}\right.$ vitamins and the proportion of $\left.\mathrm{NH}_{4}: \mathrm{K}\right)$, Q. palustris in vitro 
root growth, shoot appearance and leaf expansion benefitted from lower BAP, IAA and N levels, but a higher $\mathrm{NH}_{4}: \mathrm{K}$ ratio was beneficial for root growth [122]. DOE could be a valuable tool also in designing more efficient cryoprotectant combinations, e.g., to balance toxicity risks with acceptable osmotic stress level $[97,98]$.

\section{Final Remarks and Conclusions}

Cryobiotechnology is "the use of modern technologies to understanding the response of biological systems to low temperature environments, whether natural or imposed, and leading to the production of knowledge, goods and services, including the preservation of cells and tissues for industry, agriculture, medical science and conservation agencies" [45]. This definition goes beyond the concept of cryopreservation per se, which is directed primarily at the development of protocols for preservation, and does not articulate clearly the importance of a range of innovative technologies being used, including plant tissue culture, functional genomics, structural biology, etc. Whilst the literature on plant cryo research has increased exponentially over the last few decades [15], progress on the cryobiotechnology of Quercus and other tree species has been slowed by the need for empirical approaches, e.g., on in vitro shoot micropropagation and somatic embryogenesis [14,34]. Nonetheless, it is now known that the cryopreservation of elite genotypes over several years does not seem to change their genetic integrity after regeneration $[12,14,58,65]$. Similarly, large-scale propagation and cryopreservation of elite genotypes of $Q$. suber is being pursued [14,64], opening the window to the propagation and cryopreservation of threatened species [17]. However, to accelerate progress in the development and implementation of plant cryobiotechnology to support the bioeconomy and conservation, a conceptual framework is needed. Such a framework should take into account the challenges associated with variation in tissue complexity, provenance of material, genome and explant size, etc., based on fundamental principles of ensuring viability and structural stability.

We show here that considerable progress was made in preserving diverse propagules of oak using cryobiotechnology. We also affirmed the opportunities for establishing large-scale cryobiobanks, using pollen, embryogenic calli, somatic embryos, shoot tips, plumules and seed embryonic axes. Consequently, we believe that ex situ programmes for the conservation of tree, and other, species should not be limited to considerations of conventional seed banking but fully embrace cryobiotechnology $[11,17,18]$. In this regard, it is important to use research (Table 3) to establish standards that are acceptable to the community. For clonal crops, a successful cryopreservation is defined by a regrowth level of $20-40 \%$ [131,132]. Such a standardization of success should be applied equally to wild and threatened tree species, whether for pollen, somatic embryos, shoot tips, plumules, dormant buds or embryonic axes.

Finally, this perspective on the cryobiotechnology of Quercus species should encourage the development and implementation of similar programmes on targeted groups of species that are not easily banked conventionally and are of high conservation concern, such as within the families Arecaceae, Brunelliaceae, Chrysobalanaceae, Lauraceae, Meliaceae, Myrtaceae and Rubiaceae [1,133].

Author Contributions: D.B. and H.W.P. conceived and wrote the review paper. All authors have read and agreed to the published version of the manuscript.

Funding: This research was funded by the Garfield Weston Foundation, UK, through the Global Tree Seed Bank Project. Royal Botanic Gardens Kew receives grant-in-aid from Defra.

Acknowledgments: Quercus seeds used in our experiments were donated by the Centro Nacional de Recursos Genéticos Forestales El Serranillo, Ministerio de Agricultura y Pesca, Alimentación y Medio Ambiente of Spain. We would like to thank the Erasmus + students Pablo Bernal, Natalia Fanega and Pierre Butel for their contribution to the cryopreservation studies performed at RBG Kew.

Conflicts of Interest: The authors declare no conflict of interest. 


\section{References}

1. Rivers, M.; Shaw, K.; Beech, E.; Jones, M. Conserving the World's Most Threatened Trees: A Global Survey of Ex Situ Collections; BGCI: Richmond, UK, 2015.

2. Convention on Biological Diversity (CBD). Global Strategy for Plant. Conservation: 2011-2020; Botanic Gardens Conservation International: Richmond, UK, 2012.

3. Secretariat of the Convention on Biological Diversity. Global Biodiversity Outlook 5; Secretariat of the Convention on Biological Diversity: Montreal, QC, Canada, 2020; ISBN -9789292256883. Available online: www.cbd.int/GBO5 (accessed on 16 October 2020).

4. Guerrant, E.O.; Havens, K.; Maunder, M. Ex Situ Plant. Conservation: Supporting Species Survival in the Wild; Island Press: Washington, DC, USA, 2004; Volume 3.

5. Li, D.-Z.; Pritchard, H.W. The science and economics of ex situ plant conservation. Trends Plant Sci. 2009, 14, 614-621. [CrossRef] [PubMed]

6. United Nations Food and Agriculture Organization. Genebank Standards for Plant. Genetic Resources for Food and Agriculture; Revised edition; FAO: Rome, Italy, 2014.

7. Tweddle, J.C.; Dickie, J.B.; Baskin, C.C.; Baskin, J.M. Ecological aspects of seed desiccation sensitivity. J. Ecol. 2003, 91, 294-304. [CrossRef]

8. Wyse, S.V.; Dickie, J.B.; Willis, K.J. Seed banking not an option for many threatened plants. Nat. Plants 2018, 4, 848-850. [CrossRef] [PubMed]

9. Wyse, S.V.; Dickie, J.B. Predicting the global incidence of seed desiccation sensitivity. J. Ecol. 2017, 105, 1082-1093. [CrossRef]

10. Walters, C.; Berjak, P.; Pammenter, N.; Kennedy, K.; Raven, P. Preservation of recalcitrant seeds. Science 2013, 339, 915-916. [CrossRef] [PubMed]

11. Pence, V.C.; Ballesteros, D.; Walters, C.; Reed, B.M.; Philpott, M.; Dixon, K.W.; Pritchard, H.W.; Culley, T.M.; Vanhove, A.C. Cryobiotechnologies: Tools for expanding long-term ex situ conservation to all plant species. Biol. Conserv. 2020, 250, 108736. [CrossRef]

12. Engelmann, F. Plant cryopreservation: Progress and prospects. Vitr. Cell. Dev. Biol. Plant 2004, 40, 427-433. [CrossRef]

13. Reed, B.M. (Ed.) Plant. Cryopreservation-A Practical Guide; Springer: New York, NY, USA, 2008.

14. Vieitez, A.M.; Corredoira, E.; Martinez, M.T.; San-Jose, M.C.; Sanchez, C.; Valladares, S.; Vidal, N.; Ballester, A. Application of biotechnological tools to Quercus improvement. Eur. J. For. Res. 2012, 131, 519-539. [CrossRef]

15. Pritchard, H.W.; Nadarajan, J.; Ballesteros, D.; Thammasiri, K.; Prasongsom, S.; Malik, S.K.; Chaudhury, R.; Kim, H.-H.; Lin, L.; Li, W.-Q.; et al. Cryobiotechnology of tropical seeds-Scale, scope and hope. Acta Hortic. 2017, 1167, 37-48. [CrossRef]

16. Wang, M.R.; Chen, L.; Teixeira da Silva, J.A.; Volk, G.M.; Wang, Q.C. Cryobiotechnology of apple (Malus spp.): Development, progress and future prospects. Plant Cell Rep. 2018, 37, 689-709. [CrossRef]

17. Kramer, A.T.; Pence, V.C. The challenges of ex-situ conservation for threatened oaks. Intl. Oaks 2012, 23,91-108.

18. Pritchard, H.W.; Moat, J.F.; Ferraz, J.B.S.; Marks, T.R.; Camargo, J.L.C.; Nadarajan, J.; Ferraz, I.D.K. Innovative approaches to the preservation of forest trees. For. Ecol. Manag. 2014, 333, 88-98. [CrossRef]

19. Ballesteros, D.; Nebot, A.; Pritchard, H.W. Cryobiotechnology for the long-term preservation of oak (Quercus sp.) genetic resources. Acta Hortic. 2019, 1234, 37-46. [CrossRef]

20. Oldfield, S.; Eastwood, A. The Red List of Oaks; Fauna \& Flora International: Cambridge, UK, 2007.

21. Arroyo-Manzanares, N.; Martín-Gómez, A.; Jurado-Campos, N.; Garrido-Delgado, R.; Arce, C.; Arce, L. Target vs spectral fingerprint data analysis of Iberian ham samples for avoiding labelling fraud using headspace-Gas chromatography-ion mobility spectrometry. Food Chem. 2018, 246, 65-73. [CrossRef] [PubMed]

22. The Plant List, Version 1. 2010. Available online: http://www.theplantlist.org/ (accessed on 21 January 2018).

23. Xia, K.; Daws, M.I.; Hay, F.R.; Chen, W.Y.; Zhou, Z.K.; Pritchard, H.W. A comparative study of desiccation responses of seeds of Asian evergreen oaks, Quercus subgenus Cyclobalanopsis and Quercus subgenus Quercus. S. Afr. J. Bot. 2012, 78, 47-54. [CrossRef]

24. Bondarenko, A.S.; Butenko, O.Y. Experiment results on cryopreservation of Quercus robur L. acorns. Proc. St. Petersburg For. Res. Inst. 2015, 4, 35-47. 
25. Bonner, F.T.; Vozzo, J.A. Seed biology and technology of Quercus; General Technical Report GTR SO-66.; USDA, Forest Service: New Orleans, LA, USA, 1987.

26. Gosling, P. Handling and storing acorns \& chestnuts and sycamore fruits. For. Comm. Pract. Note 2002, 12, 1-8.

27. Bonner, F.T.; Karrfalt, R.P. (Eds.) The Woody Plant. Seed Manual; Agr Handbk 727; USDA-FS: New Orleans, LA, USA, 2008.

28. Pasquini, S.; Braidot, S.; Petrussa, E.; Vianello, A. Effect of diferent storage conditions in recalcitrant seeds of holm oak (Quercus ilex L.) during germination. Seed Sci. Technol. 2011, 39, 165-177. [CrossRef]

29. Hartmann, H.T.; Kester, D.E.; Davies, F.T., Jr.; Geneve, R.L. Plant. Propagation—Principles and Practices, 7th ed.; Prentice Hall: Upper Saddle River, NJ, USA, 2002.

30. Pence, V.C. The possibilities and challenges of in vitro methods for plant conservation. Kew Bull. 2010, 65, 539-547. [CrossRef]

31. Pence, V.C. Evaluating the costs for the in vitro propagation and preservation of endangered plants. Vitr. Cell. Dev. Biol. Plant 2011, 47, 176-187. [CrossRef]

32. González-Benito, M.E.; Martín, C. Micropropagation of Quercus ilex and in vitro conservation of Quercus suber. In Current Technologies of Forest Seed Treatment; Muller, J.V., Koziol, C., Palucka, M., Eds.; The Kostrzyca Forest Gene Bank: Miłków, Poland, 2014; pp. 56-65.

33. González-Benito, M.E.; Prieto, R.M.; Herradón, E.; Martín, C. Cryopreservation of Quercus suber and Quercus ilex embryonic axes: In vitro culture, desiccation and cooling factors. CryoLetters 2002, 23, 283-290. [PubMed]

34. González-Benito, M.E.; Martín, C. Cryopreservation of Quercus (oak) species. In Cryopreservation of Plant Germplasm II. Biotechnology in Agriculture and Forestry; Towill, L.E., Bajaj, Y.P.S., Eds.; Springer: Berlin/Heidelberg, Germany, 2002; Volume 50, pp. 312-322.

35. Chmielarz, P.; Michalak, M.; Pałucka, M.; Wasilenczyk, U. Successful cryopreservation of Quercus robur plumules. Plant Cell Rep. 2011, 30, 1405-1414. [CrossRef] [PubMed]

36. Xia, K.; Hill, L.M.; Li, D.-Z.; Walters, C. Factors affecting stress tolerance in recalcitrant embryonic axes from seeds of four Quercus (Fagaceae) species native to the USA or China. Ann. Bot. 2014, 114, 1747-1759. [CrossRef] [PubMed]

37. Brennan, A.N.; Pence, V.C.; Taylor, M.D.; Trader, B.W.; Westwood, M. Tissue culture using mature Material for the Conservation of Oaks. HortTechnology 2017, 27, 644-649. [CrossRef]

38. Corredoira, E.; Toribio, M.; Vieitez, A.M. Clonal propagation via somatic embryogenesis in Quercus spp. In Tree Biotechnology; Ramawat, K.G., Mérillon, J.M., Ahuja, M.R., Eds.; CRC Press: Boca Raton, FL, USA, 2014; pp. 262-302.

39. Pence, V.C.; Chaiken, M.F. Shoot tip cryopreservation as a conservation tool for species of Quercus: Effects of species and environment on recovery. Cryoletters 2020. accepted.

40. de Delgadillo-Díaz León, J.S.; Morales-Domínguez, J.F.; Santos-Díaz, M.S.; Pérez-Molphe-Balch, E. In vitro propagation of Mexican oaks (Quercus spp.). Politobánica 2013, 35, 85-97.

41. Purohit, V.K.; Tamta, S.; Chandra, S.; Vyas, P.; Palni, L.S.; Nandi, S.K. In vitro multiplication of Quercus leucotrichophora and Q. glauca: Important Himalayan oaks. PCTOC 2002, 69, 121-133. [CrossRef]

42. Plants of the World Online. Available online: http://www.plantsoftheworldonline.org/ (accessed on 14 October 2020).

43. The IUCN Red List of Threatened Species. Version 2017-3. Available online: www.iucnredlist.org (accessed on 14 October 2020).

44. Castillo, N.R.F.; Bassil, N.V.; Wada, S.; Reed, B.M. Genetic stability of cryopreserved shoot tips of Rubus germplasm. Vitr. Cell. Dev. Biol. Plant 2010, 46, 246-256. [CrossRef]

45. Pritchard, H.W. The rise of plant cryobiotechnology and demise of plant cryopreservation? Cryobiology 2018, 85, 160-161. [CrossRef]

46. Snyder, E.B.; Clausen, K.E. Pollen Handling. In Seeds of Woody Plants in the United States, Agric. Handb 450; Schopmeyer, C.S., Ed.; United States Department of Agriculture, Forest Service (USDA-FS): New Orleans, LA, USA, 1974; pp. 75-97.

47. Franchi, G.G.; Piotto, B.; Nepi, M.; Baskin, C.C.; Baskin, J.M.; Pacini, E. Pollen and seed desiccation tolerance in relation to degree of developmental arrest, dispersal, and survival. J. Exp. Bot. 2011, 62, 5267-5281. [CrossRef]

48. Johnson, L.P.V. The storage and artificial germination of forest tree pollens. Can. J. For. Res. 1943, 21, 332-342. [CrossRef] 
49. Batos, B.; Miljković, D.; Bobinac, M. Some characters of the pollen of spring and summer flowering common oak (Quercus robur L.). Arch. Biol. Sci. 2012, 64, 85-95. [CrossRef]

50. Steinhoff, S. Results of species hybridization with Quercus robur L. and Quercus petraea (Matt) Liebl. Ann. Sci. For. 1993, 50, 137s-143s. [CrossRef]

51. Jörgensen, J. Conservation of Valuable Gene Resources by Cryopreservation in some Forest Tree Species. J. Plant. Physiol. 1990, 136, 373-376. [CrossRef]

52. Volk, G.M. Collecting pollen for genetic resources conservation. In Collecting Plant Genetic Diversity: Technical Guidelines 2011 Update; Guarino, L., Ramanatha, V.R., Goldberg, E., Eds.; Bioversity International: Rome, Italy, 2011; pp. 1-10.

53. Ren, R.; Li, Z.; Li, B.; Xu, J.; Jiang, X.; Liu, Y.; Zhang, K. Changes of pollen viability of ornamental plants after long-term preservation in a cryopreservation pollen bank. Cryobiology 2019, 89, 14-20. [CrossRef]

54. Dinato, N.B.; Santos, I.R.I.; Vigna, B.B.Z.; de Paula, A.F.; Favero, A.P. Pollen cryopreservation for plant breeding and genetic resources conservation. CryoLetters 2020, 41, 115-127.

55. Koch, J.L.; Carey, D.W. The genetics of resistance of American beech to beech bark disease: Knowledge through 2004. In Proceedings of the Beech Bark Disease Symposium. Gen. Tech. Rep. NE-331; US Department of Agriculture, Forest Service: Newtown Square, PA, USA, 2005; pp. 98-105.

56. Batos, B.; Miljković, D. Pollen viability in Quercus robur L. Arch. Biol. Sci. 2017, 69, 111-117. [CrossRef]

57. Martinez, M.T.; Ballester, A.; Vieitez, A.M. Cryopreservation of embryogenic cultures of Quercus robur using desiccation and vitrification procedures. Cryobiology 2003, 46, 182-189. [CrossRef]

58. Sanchez, M.C.; Martinez, M.T.; Vidal, N.; San-Jose, M.C.; Valladares, S.; Vieitez, A.M. Preservation of Quercus robur germplasm by cryostorage of embryogenic cultures derived from mature trees and RAPD analysis of genetic stability. CryoLetters 2008, 29, 493-504.

59. Fernandes, P.; Loose, M.D.; Santos, C.; Roldan-Ruiz, I.; Rodriguez, E.; Pinto, G. Cryopreservation of Quercus suber somatic embryos by encapsulation dehydration and evaluation of genetic stability. Tree Physiol. 2008, 28, 1841-1850. [CrossRef]

60. Valladares, S.; Toribio, M.; Celestino, C.; Vieitez, A.M. Cryopreservation of embryogenic cultures from mature Quercus suber trees using vitrification. Cryoletters 2004, 25, 177-186. [PubMed]

61. Barra-Jiménez, A.; Aronen, T.S.; Jesús Alegre, J.; Toribio, M. Cryopreservation of embryogenic tissues from mature holm oak trees. Cryobiology 2015, 70, 217-225. [CrossRef] [PubMed]

62. Sutton, B. Commercial delivery of genetic improvement to conifer plantations using somatic embryogenesis. Ann. For. Sci. 2002, 59, 657-661. [CrossRef]

63. Harvengt, L.; Meier-Dinkel, A.; Dumas, E.; Collin, E. Establishment of a cryopreserved gene bank of European elms. Can. J. For. Res. 2004, 34, 43-55. [CrossRef]

64. Vidal, N.; Vieitez, A.M.; Fernandez, M.R.; Cuenca, B.; Ballester, A. Establishment of cryopreserved gene banks of European chestnut and cork oak. Eur. J. For. Res. 2010, 129, 635-643. [CrossRef]

65. Pence, V.C.; Philpott, M.; Culley, T.M.; Plair, B.; Yorke, S.R.; Lindsey, K.; Vanhove, A.-C.; Ballesteros, D. Survival and genetic stability of shoot tips of Hedeoma todsenii after long-term cryostorage. Vitr. Cell. Dev. Biol. Plant 2017, 53, 328-338. [CrossRef]

66. Srivastava, P.S.; Steinhauer, A. In vitro Culture of Embryo Segments of Quercus lebani: Organogenesis and Callus Growth as a Differential Response to Experimental Conditions. Z. Für Pflanzenphysiol. 1982, 106, 93-96. [CrossRef]

67. Chmielarz, P. Preservation of Quercus robur L. embryonic axes in liquid nitrogen. In Basic and Applied Aspects of Seed Biology; Ellis, R.H., Black, M., Murdoch, A.J., Hong, T.D., Eds.; Kluwer Academic Publishers: Dordrecht, The Netherlands, 1997; pp. 765-769.

68. Palucka, M.; Hrydziuszko, P. Cryogenic storage of plant material in the Kostrzyca Forest Gene Bank. In Current Technologies of Forest Seed Treatment; Muller, J.V., Koziol, C., Palucka, M., Eds.; The Kostrzyca Forest Gene Bank: Miłków, Poland, 2014; pp. 109-115.

69. Towill, L.E.; Ellis, D.D. Cryopreservation of dormant buds. In Plant Cryopreservation-A Practical Guide; Reed, B.M., Ed.; Springer: New York, NY, USA, 2008; pp. 421-442.

70. Towill, L.E.; Widrlechner, M. Cryopreservation of Salix species using sections from winter vegetative scions. CryoLetters 2004, 25, 71-80.

71. Bonnart, R.; Waddell, J.; Haiby, K.; Widrlechner, M.P.; Volk, G.M. Cryopreservation of Populus trichocarpa and Salix dormant buds with recovery by grafting or direct rooting. CryoLetters 2014, 35, 507-515. 
72. Morin, X.; Améglio, T.; Ahas, R.; Kurz-Besson, C.; Lanta, V.; Lebourgeois, F.; Miglietta, F.; Chuine, I. Variation in cold hardiness and carbohydrate concentration from dormancy induction to bud burst among provenances of three European oak species. Tree Physiol. 2007, 27, 817-825. [CrossRef]

73. Flint, H.L. Cold hardiness of twigs of Quercus rubra L. as a function of geographic origin. Ecology 1972, 53, 1163-1170. [CrossRef]

74. Bassuk, N.L.; Trowbridge, P.; Grohs, C. Visual similarity and biological diversity: Street tree selection and design. In Proceedings of the European Conference of the International Society of Arboriculture, Oslo, Norway, 18-21 June 2002.

75. Kushnarenko, S.V.; Romadanova, N.V.; Reed, B.M. Cold acclimation improves regrowth of cryopreserved apple shoot tips. Cryoletters 2009, 30, 47-54. [PubMed]

76. Towill, L.E.; Forsline, P.L.; Walters, C.; Waddell, J.W.; Laufmann, J. Cryopreservation of Malus germplasm using a winter vegetative bud method: Results from 1915 accessions. CryoLetters 2004, 25, 323-334. [PubMed]

77. Vieitez, A.M.; Ballester, A.; Amo-Marco, J.; Sanchez, M.C. Forced flushing of branch segments as a method for obtaining reactive explants of mature Quercus robur trees for micropropagation. Plant Cell Tissue Organ. Cult. 1994, 37, 287-295.

78. Ostrolucká, M.G.; Gajdošová, A.; Libiaková, G. Protocol for micropropagation of Quercus spp. In Protocols for Micropropagation of Woody Trees and Fruits; Jain, S.M., Häggman, H., Eds.; Springer: Dordrecht, The Netherlands, 2007; pp. 85-92.

79. Brennan, A.; Pence, V.; Taylor, M.; Trader, B.; Westwood, M. The effect of 6-benzylaminopurine, a cytokinin, on bud-forcing of twelve oak species. Acta Hortic. 2016, 1140, 331-334. [CrossRef]

80. Obdržálek, J.; Jílková, J. Winter grafting of oaks, Quercus L. Hortic. Sci. 2006, 33, 61-69.

81. Snyers, C. Clonal Propagation of Oaks; International Oak Society: Petersburg, IL, USA, 2013; Available online: http://www.internationaloaksociety.org/content/clonal-propagation-oaks (accessed on 30 January 2018).

82. Crecente-Campo, S.; Fernández-Lorenzo, J.L. Injerto en serie 'acelerado' de Quercus robur adulto. Cuad. Soc. Esp. Cienc. For. 2008, 24, 45-50.

83. Corredoira, E.; Martínez, M.T.; San José, M.C.; Ballester, A. Conservation of hardwood species. In Biodiversity and Conservation of Woody Plants; Ahuja, M.R., Jain, S.M., Eds.; Springer: Berlin, Germany, 2017; pp. 421-453.

84. Ballesteros, D.; Sershen Varghese, B.; Berjak, P.; Pammenter, N.W. Uneven drying of zygotic embryos and embryonic axes of recalcitrant seeds: Challenges and considerations for cryopreservation. Cryobiology 2014, 69, 100-109. [CrossRef]

85. Malik, S.K.; Choudhary, R.; Kaur, S.; Chaudhury, R.; Pritchard, H.W. Storage behavior and cryopreservation of Citrus cavaleriei, an endangered, cold-resistant species of northeast India with exceptionally large seeds. CryoLetters 2020, 41, 281-290.

86. Pence, V.C. Cryostorage of embryo axes of several large-seeded temperate tree species. Cryobiology 1990, 27, 212-218. [CrossRef]

87. González-Benito, M.E.; Pérez-Ruiz, C. Cryopreservation of Quercus faginea embryonic axes. Cryobiology 1992, 29, 685-690. [CrossRef]

88. Pence, V.C. Desiccation and the survival of Aesculus, Castanea and Quercus embryo axes through cryopreservation. Cryobiology 1992, 29, 391-399. [CrossRef]

89. Chaudhury, R. Cryopreservation of seeds, embryos, embryonic axes and pollen at National Cryobank of NBPGR. In Cryopreservation of Tropical Plant Germplasm: Current Research Progress and Application. Proceedings of an International Workshop, Tsukuba, Japan, 20-23 October 1998; Engelmann, F., Takagi, H., Eds.; International Plant Genetic Resources Institute (IPGRI): Rome, Italy, 2000; pp. 457-459.

90. Berjak, P.; Walker, M.; Watt, M.P.; Mycock, D.J. Experimental parameters underlying failure or success in plant germplasm cryopreservation: A case study on zygotic axes of Quercus robur L. CryoLetters 1999, 20, 251-262.

91. Ballesteros, D.; Fanega-Sleziak, N.; Davies, R.M. Cryopreservation of seeds and seed embryos in orthodox-, intermediate-, and recalcitrant-seeded species. In Cryopreservation and Freeze-Drying Protocols. Methods in Molecular Biology; Wolkers, W., Oldenhof, H., Eds.; Humana: New York, NY, USA, 2021; Volume 2180, pp. 663-682.

92. Vertucci, C.W. Predicting the optimum storage conditions for seeds using thermodynamic principles. J. Seed Technol. 1993, 17, 41-52. 
93. Wesley-Smith, J.; Berjak, P.; Pammenter, N.W.; Walters, C. Intracellular ice and cell survival in cryo-exposed embryonic axes of recalcitrant seeds of Acer saccharinum: An ultrastructural study of factors affecting cell and ice structures. Ann. Bot. 2014, 113, 695-709. [CrossRef]

94. Wesley-Smith, J.; Pammenter, N.W.; Berjak, P.; Walters, C. The effects of two drying rates on the desiccation tolerance of embryonic axes of recalcitrant Jackfruit (Artocarpus heterophyllus Lamk.) Seeds. Ann. Bot. 2001, 88, 653-664. [CrossRef]

95. Bernal, P.; Fanega-Sleziak, N.; Pritchard, H.W.; Ballesteros, D. Cryobiotechnological approaches for the preservation of oak (Quercus sp.) embryonic axes. Cryobiology 2018, 85, 140. [CrossRef]

96. Nadarajan, J.; Pritchard, H.W. Biophysical characteristics of successful oilseed embryo cryoprotection and cryopreservation using vacuum infiltration vitrification: An innovation in plant cell preservation. PLoS ONE 2014, 9, e96169. [CrossRef]

97. Kim, H.H.; Lee, Y.G.; Shin, D.J.; Ko, H.C.; Gwag, J.G.; Cho, E.G.; Engelmann, F. Development of alternative plant vitrification solutions in droplet-vitrification procedures. CryoLetters 2009, 30, 320-334. [CrossRef]

98. Kim, H.H.; Lee, S.C. Personalisation' of droplet-vitrification protocols for plant cells: A systematic approach to optimising chemical and osmotic effects. CryoLetters 2012, 33, 271-279.

99. Faria, J.; Hill, L.; Walters, C. Strategies to cryopreserve embryonic Axes of North American oaks: Interactions of moisture, cryoprotectants and LN exposure rates in Quercus imbricaria. Cryobiology 2019, 91, 179. [CrossRef]

100. Steiner, N.; Hill, L.; Dorr, E.; Walters, C. Development of cryobiotechnologies to preserve zygotic embryo tissues of north American tree species. In Proceedings of the 57th Annual Meeting of the Society for Cryobiology CRYO2020, Chicago, IL, USA, 21-23 July 2020.

101. Goveia, M.; Kioko, J.I.; Berjak, P. Developmental status is a critical factor in the selection of excised recalcitrant axes as explants for cryopreservation: A study on Trichilia dregeana Sond. Seed Sci. Res. 2004, 14, 241-248. [CrossRef]

102. Daws, M.I.; Pritchard, H.W. The development and limits of freezing tolerance in Acer pseudoplatanus fruits across Europe is dependent on provenance. CryoLetters 2008, 29, 189-198. [PubMed]

103. Han, E.J.; Popova, E.; Cho, G.T.; Park, S.U.; Lee, S.C.; Pritchard, H.W.; Kim, H.H. Post-harvest embryo development in ginseng seeds increases desiccation sensitivity and narrows the hydration window for cryopreservation. CryoLetters 2016, 37, 284-294. [PubMed]

104. Roach, T.; Ivanova, M.; Beckett, R.P.; Minibayeva, F.V.; Green, I.; Pritchard, H.W.; Kranner, I. An oxidative burst of superoxide in embryonic axes of recalcitrant sweet chestnut seeds as induced by excision and desiccation. Physiol. Plant. 2008, 133, 131-139. [CrossRef] [PubMed]

105. Whitaker, C.; Beckett, R.P.; Minibayeva, F.V.; Kranner, I. Production of reactive oxygen species in excised, desiccated and cryopreserved explants of Trichilia dregeana Sond. S. Afr. J. Bot. 2010, 76, 112-118. [CrossRef]

106. Berjak, P.; Sershen; Varghese, B.; Pammenter, N.W. Cathodic amelioration of the adverse effects of oxidative stress accompanying procedures necessary for cryopreservation of embryonic axes of recalcitrant seeded species. Seed Sci. Res. 2011, 21, 187-203. [CrossRef]

107. Sershen Pammenter, N.W.; Berjak, P.; Wesley-Smith, J. Cryopreservation of embryonic axes of selected amaryllid species. CryoLetters 2007, 28, 387-399.

108. Uchendu, E.E.; Leonard, S.W.; Traber, M.G.; Reed, B.M. Vitamins C and E improve regrowth and reduce lipid peroxidation of blackberry shoot tips following cryopreservation. Plant Cell Rep. 2010, 29, 25-35. [CrossRef]

109. Uchendu, E.E.; Muminova, M.; Gupta, S.; Reed, B.M. Antioxidant and anti-stress compounds improve regrowth of cryopreserved Rubus shoot tips. Vitr. Cell. Dev. Biol. Plant 2010, 46, 386-393. [CrossRef]

110. Pritchard, H.W.; Prendergast, F.G. Effects of desiccation and cryopreservation on the in vitro viability of embryos of the recalcitrant seed species Auracaria hunsteinii K. Schum. J. Exp. Bot. 1986, 37, 1388-1397. [CrossRef]

111. Berjak, P.; Farrant, J.M.; Mycock, D.J.; Pammenter, N.W. Recalcitrant (homoiohydrous) seeds: The enigma of their desiccation-sensitivity. Seed Sci. Technol. 1990, 18, 297-310.

112. Pritchard, H.W. Water potential and embryonic axis viability in recalcitrant seeds of Quercus rubra. Ann. Bot. 1991, 67, 43-49. [CrossRef]

113. Pritchard, H.W.; Manger, K.R. A calorimetric perspective on desiccation stress during preservation procedures with recalcitrant seeds of Quercus robur. CryoLetters 1998, 19, 23-30. 
114. Wesley-Smith, J.; Vertucci, C.W.; Berjak, P.; Pammenter, N.W.; Crane, J. Cryopreservation of desiccation-sensitive axes of Camellia sinensis in relation to dehydration, freezing rate and thermal properties of tissue water. J. Plant. Physiol. 1992, 140, 596-604. [CrossRef]

115. Pritchard, H.W.; Tompsett, P.B.; Manger, K.; Smidt, W.J. The effect of moisture content on the low temperature responses of Araucaria hunsteinii seed and embryos. Ann. Bot. 1995, 76, 79-88. [CrossRef]

116. González-Benito, M.E.; Herradón, E.; Martin, C. The development of a protocol for the encapsulation-desiccation and in vitro culture of Quercus suber L. and Q. ilex L. Silvae Genet. 1999, 48, $25-28$.

117. Walters, C.; Wheeler, L.; Stanwood, P.C. Longevity of cryogenically stored seeds. Cryobiology 2004, 48, 229-244. [CrossRef]

118. Pence, V.C. In vitro growth of embryo axes after long-term storage in liquid nitrogen. In Seed Conservation: Turning Science into Practice; Smith, R.D., Dickie, J.B., Linington, S.H., Pritchard, H.W., Probert, R.J., Eds.; Royal Botanic Gardens Kew: Richmond, UK, 2003; pp. 483-492.

119. Ballesteros, D.; Pence, V.C. Survival and growth of embryo axes of temperate trees after two decades of cryo-storage. Cryobiology 2019, 88, 110-113. [CrossRef]

120. Wesley-Smith, J.; Walters, C.; Berjak, P.; Pammenter, N.W. The influence of water content, cooling and warming rate upon survival of embryonic axes of Poncirus trifoliata (L.). CryoLetters 2004, 25, 129-138.

121. Niedz, R.P.; Evens, T.J. Design of experiments (DOE)—history, concepts, and relevance to in vitro culture. Vitr. Cell. Dev. Biol. Plant 2016, 52, 547-562. [CrossRef]

122. Vanhove, A.; Niedz, R.; Pence, V.C. Improving growth of Quercus palustris embryo axes in vitro: A DOE approach. Vitr. Cell. Dev. Biol. Plant 2015, 51 (Suppl. 1), S48.

123. Sha Valli Khan, P.S.; Evers, D.; Hausman, J.F. Stomatal characteristics and water relations of in vitro grown Quercus robur NL 100 in relation to acclimatization. Silvae Genet. 1999, 48, 83-87.

124. Pospíšilová, J.; Synková, H.; Haisel, D.; Semorádová, Š. Acclimation of plantlets to ex vitro conditions: Effects of air humidity, irradiance, CO2 concentration and abscisic acid (a review). Acta Hortic. 2007, 748, $29-38$.

125. Vengadesan, G.; Pijut, P.M. In vitro propagation of northern red oak (Quercus rubra L.). Vitr. Cell. Dev. Biol. Plant 2009, 45, 474-482. [CrossRef]

126. Sershen Berjak, P.; Pammenter, N.W. Effects of cryopreservation of recalcitrant Amaryllis belladonna zygotic embryos on vigor of recovered seedlings: A case of stress 'hangover'? Physiol. Plant. 2010, 139, 205-219.

127. Sershen Varghese, B.; Pammenter, N.W.; Berjak, P. Cryo-tolerance of zygotic embryos from recalcitrant seeds in relation to oxidative stress-A case study on two amaryllid species. J. Plant Physiol. 2012, 169, 999-1011. [CrossRef]

128. Wesley-Smith, J.; Walters, C.; Pammenter, N.W.; Berjak, P. Interactions among water content, rapid (nonequilibrium) cooling to $-196^{\circ} \mathrm{C}$, and survival of embryonic axes of Aesculus hippocastanum L. seeds. Cryobiology 2001, 42, 196-206. [CrossRef]

129. Corredoira, E.; San-José, M.C.; Ballester, A.; Vieitez, A.M. Cryopreservation of zygotic embryo axes and somatic embryos of European chestnut. CryoLetters 2004, 25, 33-42.

130. Wesley-Smith, J.; Walters, C.; Pammenter, N.W.; Berjak, P. Why is intracellular ice lethal? A microscopical study showing evidence of programmed cell death in cryo-exposed embryonic axes of recalcitrant seeds of Acer saccharinum. Ann. Bot. 2015, 115, 991-1000. [CrossRef]

131. Reed, B.M. Implementing cryogenic storage of clonally propagated plants. CryoLetters 2001, 22, 97-104. [PubMed]

132. Vollmer, R.; Villagaray, R.; Egusquiza, V.; Espirilla, J.; Garcia, M.; Torres, A.; Rojas, E.; Panta, A.; Barkley, N.A.; Ellis, D. The potato cryobank at the International Potato Center (CIP): A model for long-term conservation of clonal plant genetic resources collections of the future. CryoLetters 2016, 37, 318-329. [PubMed]

133. Wade, E.M.; Nadarajan, J.; Yang, X.-Y.; Ballesteros, D.; Sun, W.-B.; Pritchard, H.W. Plant species with extremely small populations (PSESP) in China: A seed and spore biology perspective. Plant Divers. 2016, 38, 209-220. [CrossRef] [PubMed]

Publisher's Note: MDPI stays neutral with regard to jurisdictional claims in published maps and institutional affiliations. 